\title{
Comparative Study on E-Government Indicators between Romania and the European Union
}

\author{
Otniel DIDRAGA, Claudiu BRANDAS \\ West University of Timisoara, Faculty of Economics and Business Administration, \\ Timisoara, Romania \\ otniel.didraga@e-uvt.ro, claudiu.brandas@e-uvt.ro
}

The development of e-government services increases the performance of the public sector by using ICT to deliver information to citizens, businesses, and public agencies. This article examines the development of e-government in Romania and compares it with the other EU countries. The indicators comparison is based on the seven e-government survey reports performed by the United Nations between 2003 and 2014 on 193 countries. The conceptual framework of the survey expresses a holistic view of the e-government development index (EGDI) and has three main dimensions: online services availability, telecommunication infrastructure, and human resource capacity. The UN global e-government ranking was intended to offer a performance rating of national governments relative to one another. Romania is ranked as a high-EGDI (between 0.5 and 0.75) country in 2014 worldwide with and EGDI value of 0.56315. Otherwise, among the EU countries, Romania is one of the low-ranked countries regarding the e-government development index in all the seven surveys. There are many opportunities for high-EGDI and middle-EGDI countries to continue e-government development. Considering EU strategies, investments in IT infrastructure, in education, and continuous transformation in online public services, there can be a considerable improvement of e-government in Romania and the other EU countries as well.

Keywords: E-Government, United Nations, EGDI, Romania, EU

1 Introduction

Information and communications technology is used to deliver information to citizens, businesses, and public agencies because of the continuous development of egovernment services. This results in increasing the efficiency and effectiveness of the public sector and administrative activities [1]; [2]; [3]. E-government helps public administration transform into an instrument of sustainable development [4]. Also, egovernment services increase information and services availability, interactivity and accessibility for citizens and businesses through the advanced use of ICT. Other advantages of using e-services are: less corruption, increased transparency, cost reductions, less bureaucracy [5]; [6].

Bureaucracy is a variable that negatively influences the financial structure and the activities of companies [7]. Effective egovernment can reduce the level of disappointment triggered by the bureaucracy in public government services use by citizens and companies [3]; [4].

This article examines the development of egovernment in Romania and compares it with the other EU countries.

\section{Literature Review}

E-Government in Romania

In Romania, before the year 2000, egovernment meant no remarkable activity [8]; [9]; [10]; [11]. However, during the last 15 years, there has been a substantial development of e-government services [12].

Since 2000, the progress of e-government projects implementation in Romania can be noticed as a government strategy attempt to make more information and services available on the Internet [12]. The success of this endeavor depends on how the citizens and the business people make use of the available services and information [6].

There are five types of e-government use, as follows [1]:

- Service use: using transactional services.

- General information use: looking up gen- 
eral information.

- Policy research: looking up information related to government policies.

- Participation: participating in decisionmaking and discussion processes.

- Co-creation: co-creating policies, information, and services with government and other citizens.

The dominant type of e-government use is the use of transactional services and infor- mation [1].

In Romania, the infrastructure developed rapidly since 2003 when the e-government portal (www.e-guvernare.ro) was launched. This infrastructure development enabled the government to provide e-government services for citizens as well as for businesses [13]. Egovernment services in Romania are portrayed in Table 1.

Table 1. E-Government services in Romania [11]

\begin{tabular}{|l|l|}
\hline \multicolumn{1}{|c|}{ Services for Citizens } & \multicolumn{1}{c|}{ Services for Businesses } \\
\hline $\begin{array}{l}\text { 1. Income taxes: declaration, notification of } \\
\text { assessment; }\end{array}$ & 1. Social contributions for employees \\
\hline 2. Job search services by labour offices; & 2. Corporate tax: declaration, notification \\
\hline 3. Social security benefits; & 3. VAT: declaration, notification \\
\hline $\begin{array}{l}\text { 4. Personal documents: passport and driver's } \\
\text { license; }\end{array}$ & 4. Registration of a new company \\
\hline 5. Car registration; & 5. Submission of data to statistical offices \\
\hline 6. Application for building permission; & 6. Customs declarations \\
\hline 7. Declaration to the police; & 7. Environment-related permits \\
\hline 8. Public libraries; & 8. Public procurement \\
\hline $\begin{array}{l}\text { 9. Certificates of birth and marriage: request } \\
\text { and delivery; }\end{array}$ & \\
\hline 10. Enrolment in higher education/university; & \\
\hline 11. Announcement of moving; & \\
\hline 12. Health related services. & \\
\hline
\end{tabular}

\section{E-Government Development Index (EGDI)}

E-government services are essential tools for enhancing urban management. The higher the level of e-government services development is, the more they can transform the interactions between the public administration, the citizens and businesses.

The United Nations state that "as a composite indicator, the e-government development index (EGDI) is used to measure the willingness and capacity of national administrations to use information and communication technologies to deliver public services" [4]. "The EGDI is based on an expert assessment survey of the online presence of all 193 United Nations Member States, which assesses national websites and how e-government policies and strategies are applied in general and in specific sectors for delivery of essential services" [4].

The degree of e-government development can be measured using the EGDI (egovernment development index) considering three dimensions: online services availability, human resource capacity and telecommunication infrastructure [4]. 
$\mathrm{EGDI}=(1 / 3 \times \mathrm{OSI})+(1 / 3 \times \mathrm{HCI})+(1 / 3 \times$ TII) [4]; [5].

The OSI (Online Service Index) 2014 is based on a four-stage model. These four stages are emerging information services, enhanced information services, transactional services and connected services [4]. The subthemes of development are: Whole-ofgovernment, Multichannel service delivery, Bridging the digital divide, Increasing usage, Open Government, and E-Participation [4]. The HCI (Human Capital Index) 2014 is a weighted average composite of four indicators: the adult literacy (one-third); the combined primary, secondary and tertiary gross enrolment ratio (two-ninth); expected years of schooling (two-ninth); and mean years of schooling (two-ninth) [4].

The TII (Telecommunication Infrastructure Index) 2014 is an arithmetic average composite of five parameters. These are: Internet users/100 inhabitants; Fixed telephone lines/100 inhabitants; Mobile subscribers/100 inhabitants; Wireless broadband subscriptions/100 inhabitants, and Fixed broadband subscriptions/100 inhabitants [4].

\section{Research Methodology \\ Research problem}

The main problem is comparing the EGDI for Romania with the EGDI for the other EU countries.

\section{Research design and data}

The research is exploratory, and it is based on a documentary study. We analyzed the United Nations e-government survey reports on 193 countries. We compared the main egovernment indicators and performed a trend analysis of data from the years 2003, 2004, 2005, 2008, 2010, 2012, and 2014. The data was processed using Microsoft@ Excel 2010 .

\section{Findings and Discussion}

The e-government development has some prerequisites [10]; [11]; [12]:

Generic indicators:

- Percentage of households with Internet access: 61\% (2014);
- Percentage of enterprises with Internet access: 85\% (2014);

- Percentage of individuals using the Internet at least once a week: $\mathbf{4 8 \%}$ (2014);

- Percentage of households with a broadband connection: 58\% (2014);

- Percentage of enterprises with a broadband connection: $\mathbf{8 2 \%}$ (2014);

- Percentage of individuals having purchased/ordered online in the last three months: 6\% (2014);

- Percentage of enterprises having received orders online within the previous year: $\mathbf{7 \%}$ (2014);

E-Government indicators:

- Percentage of individuals using the Internet for: interacting with public authorities $10 \%$, obtaining information $\mathbf{9 \%}$, downloading forms $\mathbf{5 \%}$, returning filled forms $\mathbf{3 \%}$ (2014);

- Percentage of enterprises using the Internet for: interacting with public authorities $65 \%$, obtaining information $\mathbf{5 7 \%}$, downloading forms $\mathbf{5 7 \%}$, returning filled forms $\mathbf{5 2 \%}$ (2013 - there was no data for 2014 at the time of the research).

In $2013,5 \%$ of Romanians used the Internet for e-government services, a serious decrease from $31 \%$ in 2012 and much below the EU28 average of $41 \%$, but in 2014 , there has been an increase up to $10 \%$ [11]. In 2012, 27\% of the people using the Internet were doing it for obtaining information from public authorities. In 2013, the percentage dropped to 4\%, but in 2014, the percentage increased up to $9 \%$ [11]. In 2013, 2\% of citizens sent filledin forms, down from 4\% in 2012 and much below the EU28 average of $21 \%$, but in 2014 , there has been a slight increase up to $3 \%$ [11].

Romania is ranked as a high-EGDI (between 0.5 and 0.75 ) country in 2014 worldwide with and EGDI value of $\mathbf{0 . 5 6 3 1 5}$. Otherwise, among the EU countries, Romania is one of the low-ranked countries regarding the egovernment development index in all the seven surveys from 2003-2014 (Table 2, Table 3, Figure 1, and Figure 2). 
Table 2. EGDI for Romania, its components and slope [4]; [14]; [15]; [16]; [17]; [18]; [19]

\begin{tabular}{|c|c|c|c|c|}
\hline Year & EGDI & OSI & HCI & TII \\
\hline $\mathbf{2 0 0 3}$ & 0.48278 & 0.41921 & 0.88000 & 0.14914 \\
\hline $\mathbf{2 0 0 4}$ & 0.55035 & 0.60617 & 0.88000 & 0.16488 \\
\hline $\mathbf{2 0 0 5}$ & 0.57040 & 0.64230 & 0.88000 & 0.18890 \\
\hline $\mathbf{2 0 0 8}$ & 0.53830 & 0.41471 & 0.90474 & 0.29920 \\
\hline $\mathbf{2 0 1 0}$ & 0.54791 & 0.41587 & 0.92260 & 0.30927 \\
\hline $\mathbf{2 0 1 2}$ & 0.60595 & 0.51633 & 0.87829 & 0.42322 \\
\hline $\mathbf{2 0 1 4}$ & 0.56315 & 0.44094 & 0.81000 & 0.43854 \\
\hline Slope (trend) & 0.0054 & -0.0085 & -0.0032 & 0.0280 \\
\hline
\end{tabular}

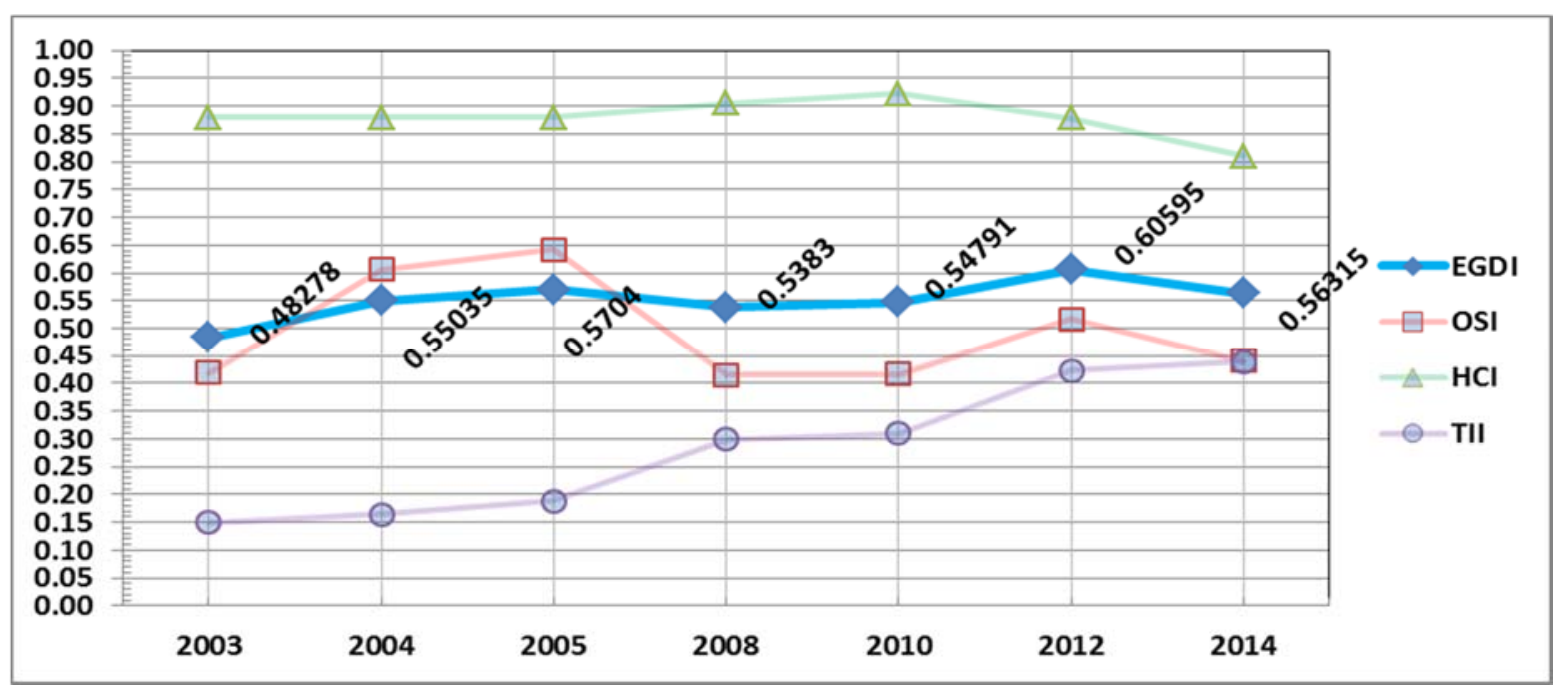

Fig. 1. EGDI for Romania [4]; [14]; [15]; [16]; [17]; [18]; [19]

Romania's overall e-government development index increased in 2004, 2005, 2010 and 2012 (the best value: 0.60595 ), but it decreased in 2008 and 2014. The trend analysis shows that the EGDI improves slowly with a positive trend value of 0.0054 . The trend analysis for the OSI shows a slight decrease with a trend value of -0.0085 . The OSI increased in 2004, 2005, 2010 and 2012, but it drastically decreased in 2008, and 2014.
A similar decrease in trend (slope) can be observed in the HCI (-0.0032). The HCI recorded a standstill at 0.88 between 2003 and 2005. Then, it increased in 2008 and 2010 and decreased in 2012 at 0.87829 , and to the minimum level in 2014 (0.81).

The trend analysis for the telecommunication infrastructure index reveals a positive value (0.0280). The TII increased throughout the whole period between 2004-2014.

Table 3. EGDI for Romania compared to the EU countries [4];[14];[15];[16];[17];[18];[19]

\begin{tabular}{|c|c|c|c|c|c|}
\hline Year & $\begin{array}{c}\text { Romania's } \\
\text { Rank out of 28 }\end{array}$ & $\begin{array}{c}\text { EGDI of } \\
\text { Romania }\end{array}$ & Max (EU) & Min (EU) & Avg (EU) \\
\hline $\mathbf{2 0 0 3}$ & 27 & 0.48278 & $\begin{array}{c}0.83967 \\
\text { Sweden }\end{array}$ & $\begin{array}{c}0.47406 \\
\text { Cyprus }\end{array}$ & 0.63678 \\
\hline $\mathbf{2 0 0 4}$ & 23 & 0.55035 & 0.90466 & 0.51886 & 0.66561 \\
\hline
\end{tabular}




\begin{tabular}{|c|c|c|c|c|c|}
\hline $\mathbf{2 0 0 5}$ & 26 & 0.57040 & $\begin{array}{c}0.90576 \\
\text { Denmark }\end{array}$ & $\begin{array}{c}0.54802 \\
\text { Croatia }\end{array}$ & 0.68481 \\
\hline $\mathbf{2 0 0 8}$ & 28 & 0.53830 & $\begin{array}{c}0.91570 \\
\text { Sweden }\end{array}$ & $\begin{array}{c}0.53830 \\
\text { Romania }\end{array}$ & 0.69280 \\
\hline $\mathbf{2 0 1 0}$ & 28 & 0.54791 & $\begin{array}{c}0.81466 \\
\text { UK }\end{array}$ & $\begin{array}{c}0.54791 \\
\text { Romania }\end{array}$ & 0.65469 \\
\hline $\mathbf{2 0 1 2}$ & 28 & 0.60595 & $\begin{array}{c}0.91249 \\
\text { Netherlands }\end{array}$ & $\begin{array}{c}0.60595 \\
\text { Romania }\end{array}$ & 0.74824 \\
\hline $\mathbf{2 0 1 4}$ & 27 & 0.56315 & $\begin{array}{c}\text { 0.89384 } \\
\text { France }\end{array}$ & $\begin{array}{c}0.54209 \\
\text { Bulgaria }\end{array}$ & 0.73003 \\
\hline
\end{tabular}

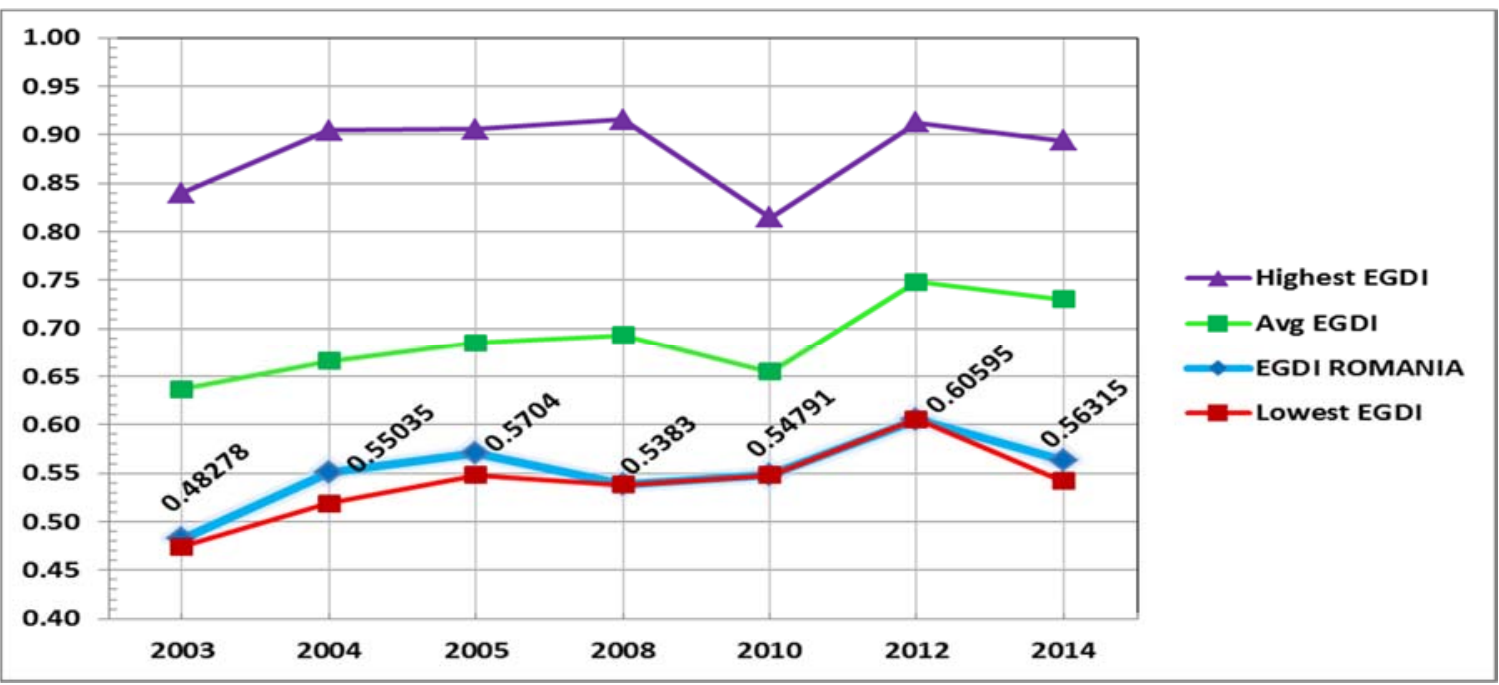

Fig. 2. EGDI of Romania compared to the EU countries [4];[14];[15];[16];[17];[18];[19]

We can see that although Romania has a medium EGDI in 2003 (0.48278) and a high EGDI between 2004 and 2014, the ranking within the EU is very low, and the average EGDI is much higher than Romania.

The highest EGDI values between 2003 and 2008 are for Sweeden and Denmark, two Nordic countries because of the online services index and the telecommunication infrastructure index [16]; [17]; [18]; [19]. Later, the highest EGDI is recorded in the UK in 2010 (0.81466) [15], the Netherlands in 2012 (0.91249) [14] and France in 2014 (0.89384) [4]. France is ranked first considering the online service delivery worldwide in 2014, overcoming even Singapore and South Korea [4] thanks to eservices integration, extended roll-out of mobile applications and commitment to continuous improvement in public service [4].
The lowest EGDI in 2003 and 2004 is for Cyprus because of the low on-line presence [18]; [19]. In 2005, Croatia had an EGDI of 0.54802 , ranking the lowest in the EU (with the remark that Croatia joined the EU only in 2013) because the online services offered were not yet substantiated, and e-government was covering only basic services like providing standard information on laws, government structure, and projects and activities [17].

Later, the lowest EGDI in the EU is unfortunately recorded for 3 years in a row for Romania: $2008-0.53830$ [16], $2010-$ 0.54791 [15], and $2012-0.60595$ [14]. In 2014, Bulgaria ranked the last among the EU countries with the lowest EGDI: 0.54209 [4]. In Figure 3, we presented the evolution of the online services index of Romania, the highest OSI, the lowest OSI and the average OSI in the EU between 2003 and 2014. 


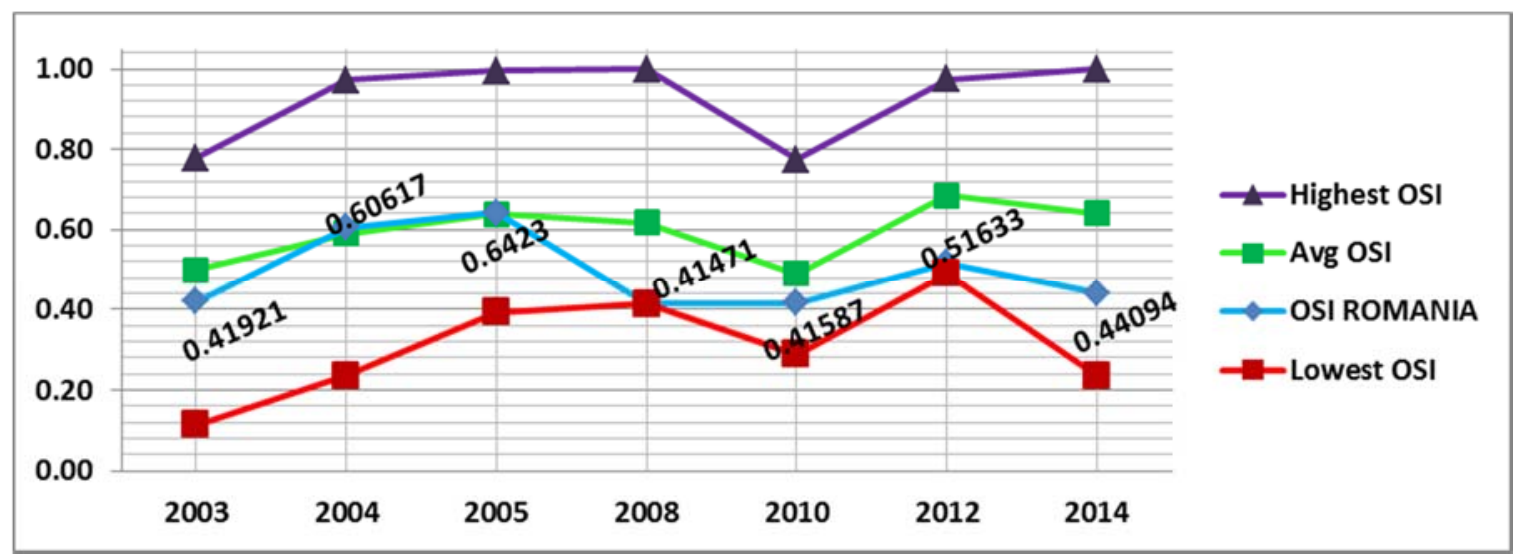

Fig. 3. OSI of Romania compared to the EU countries $[4] ;[14] ;[15] ;[16] ;[17] ;[18] ;[19]$

The highest values of the OSI in 2003 (0.77729), 2004 (0.97297), 2005 (0.99615), $2010(0.7746)$, and $2012(0.97385)$ are for the UK, in 2008 (1.00) for Denmark, and 2014 (1.00) for France.

The lowest values of the OSI in 2003 (0.11353), and $2004(0.23552)$ are for Cyprus; in 2005 (0.3923) for Spain; in 2008
(0.41471) for Greece; in $2010(0.28888)$ for Italy; in 2012 (0.49019) and $2014(0.23622)$ for Bulgaria.

In Figure 4, we presented the evolution of the human capital index of Romania, the highest $\mathrm{HCI}$, the lowest HCI and the average HCI in the EU between 2003 and 2014.

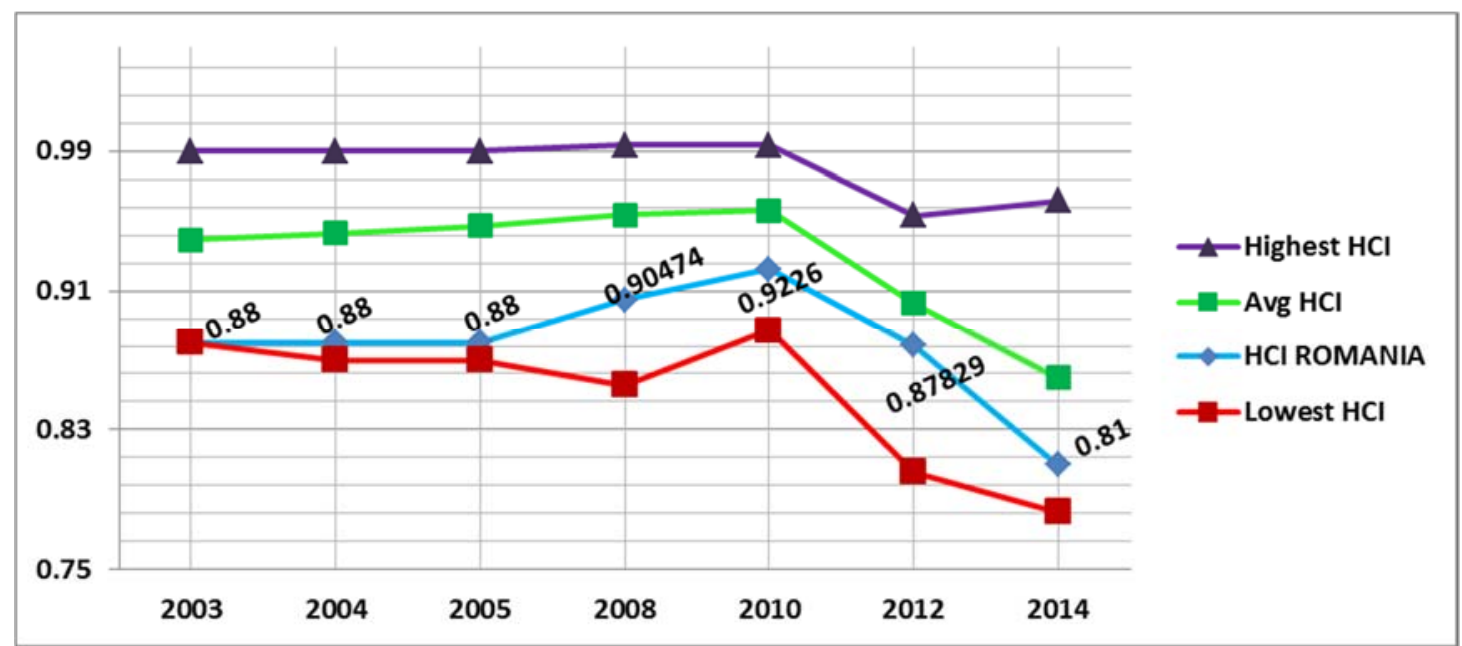

Fig. 4. HCI of Romania compared to the EU countries [4];[14];[15];[16];[17];[18];[19]

The highest values of the HCI are: in 2003 and 2005 for Belgium, Finland, The Netherlands, Sweeden, and the UK (0.99); in 2004 for Belgium, Denmark, Finland, The Netherlands, Sweeden, and the UK (0.99); in 2008 and 2010 for Denmark and Finland (0.99333); in 2012 (0.9535), and in 2014 (0.9619) for Ireland.

The lowest values of the HCI are: in 2003 for Croatia, Cyprus, Malta and Romania (0.88); and for Malta in $2004(0.87)$, in 2005 (0.87), in $2008(0.85558)$, in $2010(0.88703)$, in 2012 (0.8057); and for Cyprus in 2014 (0.7828).

In Figure 5, we presented the evolution of the telecommunication infrastructure index of Romania, the highest TII, the lowest TII and the average TII in the EU between 2003 and 2014. 


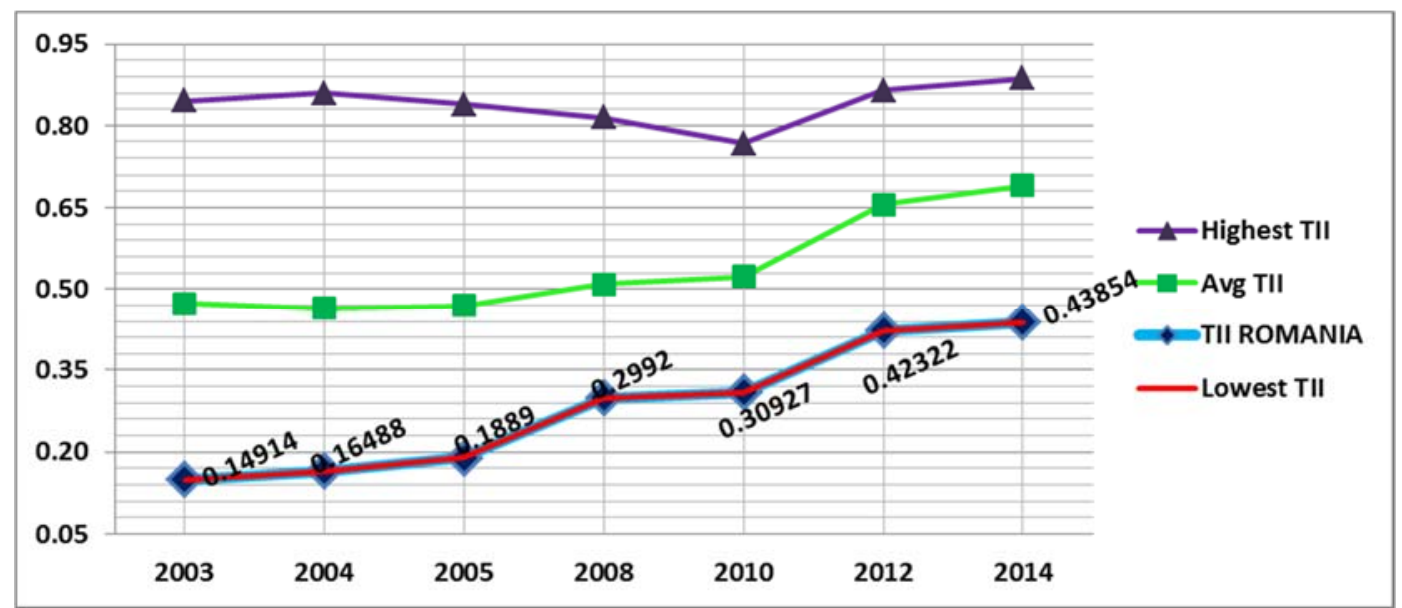

Fig. 5. TII of Romania compared to the EU countries [4];[14];[15];[16];[17];[18];[19]

The highest values of the TII are: in 2003 (0.84563), 2004 (0.85999), 2005 (0.83952), and $2014(0.88656)$ for Sweden; in 2008 (0.81402), and $2010(0.7666)$ for The Netherlands; and in 2012 (0.86437) for Luxembourg.

The lowest values of the TII are for Romania in all the surveys: 2003 (0.14914), 2004 (0.16488), 2005 (0.1889), 2008 (0.2992), 2010 (0.30927), 2012 (0.42322), and 2014 (0.43854).

In 2013 , only $41 \%$ of the EU28 population used e-government services, down from $44 \%$ in 2012 [9]. Currently, only 9 out of 28 countries are exceeding the 2015 target of 50\%: Denmark, The Netherlands, Sweden, Finland, France, Luxembourg, Austria, Slovenia and Belgium, and only 7 countries have seen an increase in use in 2013 [9].

In Romania, Italy, Bulgaria, Poland and Croatia, online public services are used by less than $25 \%$ of the population with very little progress in terms of recovery [9].

According to the European Commission [20], in 2015, the digital public services score increased in Romania (0.31) compared with 2014 (0.27). Nevertheless, the use of egovernment is still the lowest in the EU, partly due to the low level of development of online public services [20].

The less developed countries can benefit from the lessons learnt from other "confirmed" e-government practices. They can avoid potential risks and accelerate the development of e-government [4].

\section{Conclusions}

The development of e-government services increases the performance of the public sector by using ICT to deliver information to citizens, businesses, and public agencies. We examined the development of e-government in Romania and compared it with the other EU countries. The indicators comparison was based on the seven e-government survey reports performed by the United Nations between 2003 and 2014 on 193 countries.

The e-government development index (EGDI) has three main dimensions: online services availability, human resource capacity, and telecommunication infrastructure.

Romania is ranked as a high-EGDI (between 0.5 and 0.75 ) country in 2014 worldwide with and EGDI value of 0.56315 . However, among the EU countries, Romania is one of the low-ranked countries regarding the egovernment development index in all the seven surveys.

The most recent survey data (2014) shows considerable asymmetry regarding the online service delivery. The gap between the highest and lowest scores on online service and between the different stages of e-service development is significant, even though some countries recorded progress in several areas.

Many countries scored low on the Online 
Service Index (OSI) in 2014. However, as technology evolves, improved access to telecommunication infrastructure has facilitated the development of e-government in some countries, but, generally, the most advanced countries (Denmark, The Netherlands, The United Kingdom, Sweden, Luxembourg, Finland, France, Austria) have continued to leave behind the less developed countries in online service delivery (Romania, Bulgaria, Slovakia, Cyprus, Croatia).

The citizens can benefit from better access to information, advanced e-service delivery, efficient government management and enhanced interactions with the government, primarily due to the development of ICT in the public sector. Thus, governments should take measures to improve e-services.

Many countries have published much information online, even more than just websites in order to provide national web portals as starting points for users to access government services. The developing countries should improve transactional services and the electronic means of involving citizens in public consultation and even decision-making.

The less developed countries (including Romania) should concentrate on enhanced literacy skills, on extensive government online presence, and improved access, especially to broadband, through both national efforts and international cooperation. E-government can be essential for Romania's development. Providing efficient egovernment services, there will be a better transparency of different systems in Romania such as public procurement, education, health, and social protection. Romania has the opportunity to develop the electronic public services by using knowledge from the results and experiences of other more developed European countries.

Considering EU strategies, investments in IT infrastructure, in education, and continuous transformation in online public services, there can be a considerable progress of egovernment in Romania and the other EU countries as well.

\section{Acknowledgment}

This work was cofinanced from the European Social Fund through Sectoral Operational Programme Human Resources Development 2007-2013, project number POSDRU 159/1.5/S/142115 "Performance and excellence in doctoral and postdoctoral research in Romanian economics science domain".

\section{References}

[1] T. Nam, "Determining the type of egovernment use", Government Information Quarterly, vol. 31, 2014, pp. 211-220.

[2] MCSI, Strategia Națională privind Agenda Digitală pentru România 2020 - Februarie 2015 , http://www.mcsi.ro/CMSPages/GetFile.a spx?nodeguid $=0617 \mathrm{c} 1 \mathrm{~d} 7-182 \mathrm{f}-44 \mathrm{c} 0$ a978-4d8653e2c31d.

[3] M.D. Tesu, "Developing E-Government for Better Public Services Within European Union", Theoretical and Empirical Researches in Urban Management, Vol. 7, Issue 2, May 2012, pp. 79-88.

[4] United Nations, UN E-Government Survey 2014 - E-Government for the Future We Want, ISBN: 978-92-1123198-4, United Nations New York, Retrieved March 16, 2015 from http://unpan3.un.org/egovkb/Portals/egov $\mathrm{kb} /$ Documents/un/2014-Survey/EGov_Complete_Survey-2014.pdf.

[5] S. Alshomrani, "A Comparative Study on United Nations E-Government Indicators between Saudi Arabia and USA", Journal of Emerging Trends in Computing and Information Sciences, vol. 3, no. 3, 2012, pp. 411-420.

[6] S.E. Colesca and L. Dobrica, "Adoption and Use of E-Government Services: The Case of Romania", Journal of Applied Research and Technology, vol. 6, no. 3, December 2008, pp. 204-217.

[7] A. Ionescu and P. Tudoreanu, "The Impact of Corporate Governance Dimensions on Financial Structure of the Companies in Developing Countries", Annals of the „Constantin Brâncuşi”" 
University of Târgu Jiu, Economy Series, Issue 6, 2014, ISSN 2344 - 3685, pp. 2329.

[8] European Commission, Delivering the European Advantage? 'How European Governments can and should benefit from innovative public services' - eGovernment Benchmark - May 2014, Luxembourg, Publications Office of the European Union, ISBN 978-92-7938052-5.

[9] European Commission, Digital Agenda Scoreboard 2014 - Romania, Retrieved March 18, 2015 from http://ec.europa.eu/digitalagenda/en/scoreboard/romania.

[10] O. Stoica, "E-Government Implementation in Romania. From National Success to International Example", 2009, Retrieved March 21, 2015 from http://www.nispa.org/conf_paper_detail.p hp? $\mathrm{cid}=17 \& \mathrm{p}=1549 \& \mathrm{pid}=166$.

[11] European Commission, eGovernment in Romania, Edition 12.0 - eGovernement Factsheets, January 2015, Retrieved March 21, 2015, from https://joinup.ec.europa.eu/sites/default/fi les/egov_in_romania_-_january_2015_v.12.0 final.pdf

[12] O. Didraga and C. Brandas, "Study on the E-Government State of Play in Romania", Multidisciplinary Academic Conference on Economics, Management and Marketing (MAC-EMM 2014), December 5-6, 2014.

[13] S.E. Colesca and L. Dobrica, "Egovernment Adoption in Romania", International Journal of Social, Management, Economics and Business Engineering, vol. 2, no. 6, 2008, pp.7579.

[14] United Nations, UN E-Government Survey 2012 - E-Government for the People, ISBN: 978-92-1-123190-8, United Nations New York, Retrieved March 16, 2015 from http://unpan3.un.org/egovkb/Portals/egov $\mathrm{kb} /$ Documents/un/2012-

Survey/Complete-Survey.pdf.

[15] United Nations, UN E-Government Survey 2010 - Leveraging E-Government at a Time of Financial and Economic Crisis, ISBN: 978-92-1-123183-0, UN New York, Retrieved March 16, 2015, from

http://unpan3.un.org/egovkb/Portals/egov $\mathrm{kb} /$ Documents/un/2010-

Survey/Complete-survey.pdf.

[16] United Nations, UN E-Government Survey 2008 - From E-Government to Connected Governance, ISBN: 978-92-1123174-8, UN New York, Retrieved March 16, 2015, from http://unpan3.un.org/egovkb/portals/egov $\mathrm{kb} /$ Documents/un/2008-

Survey/unpan028607.pdf.

[17] United Nations, UN Global EGovernment Readiness Report 2005 From E-Government to E-Inclusion., UN New York, Retrieved March 16, 2015, from

http://unpan3.un.org/egovkb/Portals/egov $\mathrm{kb} /$ Documents/un/2005-

Survey/Complete-survey.pdf.

[18] United Nations, UN Global EGovernment Readiness Report 2004 Towards Access for Opportunity, UN New York, Retrieved March 16, 2015, from

http://unpan3.un.org/egovkb/portals/egov $\mathrm{kb} /$ Documents/un/2004-

Survey/Complete-Survey.pdf.

[19] United Nations, UN Global EGovernment Survey 2003, UN New York, Retrieved March 16, 2015, from http://unpan3.un.org/egovkb/portals/egov $\mathrm{kb} /$ Documents/un/2003Survey/unpan016066.pdf.

[20] European Commission, DESI 2015 Country Profiles - Romania, published on 19.02.2015, Retreived March 21, 2015, from http://ec.europa.eu/newsroom/dae/docum ent.cfm?doc_id=8774. 


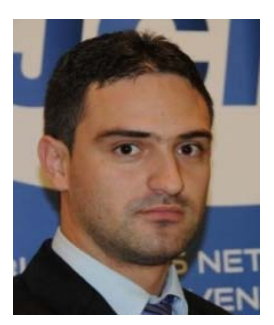

Otniel DIDRAGA graduated the Faculty of Economics and Business Administration in Timisoara in 2005. He holds a Ph.D. diploma in Management since 2012. In 2005 he joined the staff of the West University of Timisoara - Faculty of Economics and Business Administration. He is an Assistant Professor in the Department of Business Information Systems at the Faculty of Economics and Business Administration - West University of Timisoara. Currently, his research interests include IT Project Management, Risk Management, Business Information Systems Analysis and Design, Information Systems Control and Audit, E-Government Projects Risk Management.

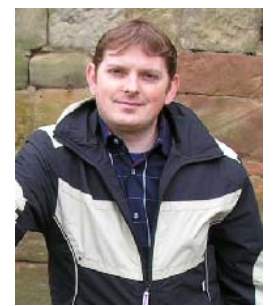

Claudiu BRANDAS is Associate Professor, Ph.D. at the West University of Timisoara, Faculty of Economics and Business Administration, Department of Business Information Systems and Statistics. He earned his Ph.D. from the "Babes-Bolyai" University of Cluj-Napoca, the Faculty of Economics in Decision Support Systems conception and design. Currently, his research interests include DSS (Decision Support System), Business Intelligence, Collaborative Systems, Business Information Systems Analysis and Design, Business Process Modeling, Information Systems Control and Audit and Software Project Management. 